\title{
Predictors of Learning Satisfaction in Japanese Online Distance Learners
}

\author{
Eric Bray \\ Yokkaichi University, Japan \\ Kumiko Aoki \\ National Institute of Multimedia Education, Japan

\section{Larry Dlugosh} \\ University of Nebraska-Lincoln, USA
}

\begin{abstract}
Japanese distance education has been slow to utilize the Internet, and mainly depends on the mail system and, to a lesser extent, television broadcasting as its mode of delivery. Since 2001, however, regulations have been relaxed to allow students to complete all course requirements for a university degree via online distance learning. This paper reports the results of a questionnaire study administered to the students $(N=424)$ enrolled in one of Japan's few online distance universities. Satisfaction with learning was explored by examining students' opinions and learning preferences in regard to five aspects of distance learning identified as important: (1) learner-teacher interaction, (2) learner-content interaction, (3) learner-learner interaction, (4) learner-interface interaction, and (5) student autonomy. In addition, the analysis included students' responses to three open-ended questions. Results indicate that students were generally satisfied with their learning, and that, specifically, learning satisfaction was higher for students who: (1) could persevere in the face of distance learning challenges, (2) found computers easy to use, (3) found it easy to interact with instructors, and (4) did not prefer social interaction with others when learning.
\end{abstract}

Keywords: Japan; distance learning; distance education; online learning, online education; e-learning

\section{Introduction}

Garrison and Shale (1987) wrote that the distinguishing feature of distance education was that it could "extend access to education to those who might otherwise be excluded from an educational experience” (p. 10). Now 20 years later, access to learners has greatly increased due to several factors, one of the most important factors being technological developments facilitating the worldwide spread of the Internet. Particularly, adult learners 
who live at a distance from educational institutions, or who lack the time to attend face-toface classes due to the demands of work and family, have benefited from the growth of distance learning, and older "non-traditional students," make up the majority of many postsecondary distance learning programs.

Despite the successes in terms of increased access to education, quality issues are still much debated in regard to distance learning. Although the question of whether distance learning courses can be as effective as face-to-face courses has largely been answered in the affirmative (Russell, 1999), teachers and program designers still face challenges in deciding how to best design learning programs so that they will be effective for a broad range of students. Anderson (2003) has written of the challenge of "getting the mix right" among three dimensions of learning: (1) teacher interaction, (2) content interaction, and (3) student interaction. Anderson's equivalency theorem states that individual students may need or may prefer different mixes of activity types, and, importantly, if the quality of the educational experience in any one dimension of interaction is high enough, "sufficient levels of deep and meaningful learning can be developed...” (p. 4). This theorem supports learner differences and counters the idea that there is one best way to teach or learn at a distance.

When designing distance learning programs, the task of "getting the mix right" becomes more challenging within the growing cross-border educational contexts that distance learning facilitates. Asian countries, with their large populations and growing economies, stand well-poised to benefit from the development of distance learning, both in their own educational institutions and when their students attend the institutions across borders via distance education. Theorists (Hofstede, 1986; Moore, 2006; Swan, 2004), however, have suggested there may be important differences in how students from different cultures view the learning process and prefer it to take place.

Jin and Cortazzi (1998), in a cross-cultural questionnaire study with Chinese and British students attending traditional lecture classes in their own countries, found differences in the "culture of learning," and, in particular, views on the ideal role of the teacher in the learning process. Gunawardena, Nolla, Wilson, Lopez-Islas, Ramirez-Angel, et al. (2001), in a large cross-cultural questionnaire study with Mexican and American students, found cultural values affected perceptions of group development processes when students interacted online. Morse's (2003) exploratory case study with online learners found that a group of mixed Asian students had stronger preferences for immediate feedback from the teacher and a greater interest in interaction with other students than did a group of predominantly New Zealander students. New Zealander students, on the other hand, were more appreciative of the convenience provided by distance learning than were Asian students. Morse therefore suggests it may be a mistake to assume that "one size fits all" when teaching online classes with learners from other cultures, because although these two groups were culturally dissimilar, the Asian students were even more dissimilar because they were studying as foreign students using a second language.

With the increase in cross-border educational contacts facilitated by the Internet, there is a greater need for understanding of the approaches to learning required to support students from other cultures in order to "get the mix right" and to avoid projecting false or stereotypical images onto them or ignoring important differences. To meet this need, the present study was undertaken with the students of one of Japan's few online distance universities to determine the relationships between their learning satisfaction and (1) their 
Bray, Aokyi \& Dlugosh

opinions about distance learning, (2) general learning preferences, and (3) demographic variables.

\section{Japanese Education Background}

Japanese higher education is well-developed with a 50.1 percent advancement rate from high schools to degree-granting institutions; it is also dominated by traditional students, ages 18 to 22 (MEXT, 2006). Although rigorous study for university entrance exams often occurs in the high school years, university degree programs are generally considered less demanding, and the graduation rate for Japanese university students (91\%) is the highest of the 30 countries surveyed by the OECD, which showed the average graduation rate of 71 percent (OECD, 2007). Japanese distance education, however, is more focused on providing educational opportunities to non-traditional-aged students, particularly those who are already working or having responsibilities at home. In 2007, 274,120 students were seeking degrees in 57 distance learning programs, accounting for 9.7 percent of total higher education enrollees (MEXT, 2007). Fifty-four of these programs are actually the correspondence education divisions of existing universities, while three of the programs were distance learning institutions.

It is important to note that Japan has been relatively slow to utilize the Internet in its distance learning programs, and a considerable amount of its distance education still utilizes the mail system or, to a lesser extent broadcast television, as its mode of delivery. In 2003, Japan ranked 23rd in e-learning readiness rankings done by the Economist Intelligent Unit and IBM (2003), lagging behind Korea (ranked 5th) and Singapore (ranked 6th). Central government policy coordinated through the Ministry of Education, Culture, Sports and Technology (MEXT), has much responsibility for this, as it strongly regulates both public and private universities.

Distance education via the mail system (i.e., correspondence learning) was first recognized by the MEXT in 1950, and since then it has been regulated differently from traditional oncampus education. Until 1998, MEXT required that 30 credits out of the 124 credits required for graduation be taken through face-to-face classroom teaching, called "schooling." In March 1998, this regulation was relaxed to allow the 30 credits to be taken through synchronous media such as videoconferencing. Three years later, in March 2001, it was relaxed again to allow the 30 credits to be taken through videoconferencing via the Internet. This made it possible for distance education programs to exist solely at a distance without requiring students to come to a campus or a study centre. The university where this study took place opened in 2004, and remains only one of a few universities in Japan where students can study entirely online at a distance.

Although government regulations have been relaxed, few programs utilize the Internet for distance learning in any substantial way. There has been much discussion about the possible reasons for this, including administrative and faculty resistance to change; however, some educators in Japan suggest that another reason may be that Japanese cultural values and educational traditions, which typically emphasize teacher-directed learning within a context rich face-to-face environment, may conflict with a form of educational delivery that emphasizes student autonomy and communication through electronic media at a distance (Jung \& Suzuki, 2006; Kubota \& Fujikawa 2007; McCarty, 1999). Research on Japanese distance learners' views remains lacking, however, and opinions about distance learning's potential often are based on educators' experiences with 
traditional face-to-face students or on small case studies with distance learners. For example, Kubota and Fujikawa (2007), in one of the few studies examining distance learning in Japan, found many undergraduates studying in a distance version of an Introductory Finance class, would not recommend the course to a friend. It should be noted, however, that these students were enrolled in a traditional face-to-face university degree program and taking one experimental distance learning course, and as such, these results may not be applicable to other learner groups, and specifically adult learners who selfselect to study in a distance learning institution. The present study, therefore, has the goal of bringing the opinions and preferences of students who study in a distance learning institution into this discussion of the suitability of distance learning for Japanese learners.

\section{Literature Review - Study variables}

\section{Learning Satisfaction}

"Student-perceived learning" or "learning satisfaction" often are included as dependent variables in distance learning research (Chen \& Willits, 1998; Fredericksen, Pickett, Shea, Pelz, \& Swan, 2000; Marks, Sibley \& Arbaugh, 2005; Stein, Wanstreet, Calvin, Overtoom $\&$ Wheaton, 2005). These function as indicators of learning itself, and are used because of the inconsistencies associated with teachers' measuring internal processes that are not directly observable. Knowing the predictors of learning satisfaction would be useful to inform program design and learner support systems in related programs, and as a consequence, the present study was designed to determine which aspects of students' distance learning experience were important influences on learning satisfaction.

\section{Distance Learning}

Initially, a literature review was performed to identify the aspects of students' distance learning experience most likely to influence learning satisfaction. Review of the work of Moore (1989; 1972) revealed four important aspects of the distance learning experience: (1) learner-teacher interaction, (2) learner-content interaction, (3) learner-learner interaction, and (4) learner autonomy. These four aspects of the learning experience were selected as the main study variables. A fifth aspect of the learning experience discussed by Hillman, Willis, and Gunawardena (1994), learner-Interface Interaction, was added as a minor study variable (See Table 1). 
Table 1. Study variables

\begin{tabular}{|l|l|}
\hline \multicolumn{1}{|c|}{ Independent Variables } & Dependent Variable \\
\hline Learner Autonomy & Learning Satisfaction \\
\hline Learner-Teacher Interaction & \\
\hline Learner-Content Interaction & \\
\hline Learner-Learner Interaction & \\
\hline Learner-Interface Interaction & \\
\hline
\end{tabular}

It should be noted that learner-content interaction was defined differently from Moore's writings about course structure. Moore focused on the rigidity of course structure, which he proposed leads to greater transactional distance, defined as a "gap of communication and understanding between the teacher and learners" (Moore \& Kearsley, 2005, p. 223). The present study, instead, focused on the clarity of course content following the work of Chen and Willits (1998) and Stein, Wanstreet, Calvin, Overtoom and Wheaton (2005), who proposed that course structure also could function to reduce transactional distance and act as a facilitator of learning at a distance.

\section{Research Questions}

Research Question 1: In general, how satisfied were students with their learning in this online distance education program?

Research Question 2: To what extent was student learning satisfaction predicted by a regression model containing the questionnaire subscales, and the demographic variables?

\section{Methods}

\section{Study Population}

The population of this study was comprised of undergraduate students enrolled in an online distance university located in a major urban area of Japan. Students attending this university take all, or nearly all, of their classes via the distance mode. Approximately half the classes offered utilize synchronous lectures that students can watch and respond to from their homes in real time. Recorded versions of these lectures, however, also are made available for students to view at times they find convenient, and the majority of classes are viewed in this manner. In addition, approximately half of the classes offered are much like traditional correspondence classes, in which students read textbooks, write assignments, and take tests at home. Nonetheless, students do use the Internet to submit their work to their teachers via a drop-box in the class website. 
Bray, Aokyi \& Dlugosh

\section{Instrumentation}

A questionnaire, the Distance Learning Questionnaire (DLQ), was developed by the researchers for use in this study and contained closed-ended Likert five-point scale items (ranging from 1 (strongly disagree) to 5 (strongly agree), open-ended question items and demographic items. The DLQ contained the following three main sections: (1) Opinions of Distance Learning, (2) General Learning Preferences, and (3) Demographic Information.

The main scale in this study was the Opinions of Distance Learning Scale, consisting of 18 items. Four items were written for each of the four main study variables, and two items were written for the minor study variable, Learner-Interface Interaction. The second scale, General Learning Preferences, consisted of eight items, with two items written for each of the four main study variables. Items were generally phrased in terms of ease or difficulty of interaction within each variable. For example, in regard to learner-learner interaction, two of the four items were:

Item 4: It is easy to exchange opinions with other students about the course.

Item 15: It is difficult to develop relationships with other students.

In addition, two items were developed to measure the level of student satisfaction, and these were worded differently:

Item 10: All in all, I am satisfied with my learning in this distance learning program.

Item 21: All in all, based on my own experience, I would not recommend distance learning to my friends.

Finally, three open-ended items were added to this questionnaire following the assumption that "collecting diverse types of data best provides an understanding of a research problem" (Creswell, 2003, p. 2). The three open-ended items were:

Item 11: In terms of your learning, what are the advantages of distance education?

Item 22: In terms of your learning, what are the difficult aspects of distance education?

Item 31: Thinking about your learning in general, what is your learning style and how do you prefer to learn?

Students' responses to the open-ended items were first translated into English and then coded and placed in themes, where percentages of each theme were calculated to facilitate comparison.

\section{Procedures}

Questionnaire development began in March 2005, based on a literature review and the distribution of an exploratory open-item questionnaire, as well as interviews with students and staff at the university. The questionnaire was first written in English and then, in 
cooperation with one of the research team members who is Japanese and also a fluent English speaker, was translated into a Japanese version. To check reliability, backtranslation into English was later performed by professional translators unfamiliar with the project. Finally the questionnaire was made available to students on the university's website in December 2006.

\section{Data Analysis}

The main form of data analysis to be presented is the results of the multiple regression analysis used to determine what aspects of the students' experience best predicted student learning satisfaction. Subscale means and means of individual items are presented where they were able to add to the analysis. Results of the qualitative data are presented separately and later converged in the discussion section as suggested by Creswell and Plano Clark (2007).

\section{Results}

\section{Demographic Results}

Of the 1,414 students enrolled in the university at the time the questionnaire was made available to students, 424 completed the entire questionnaire, resulting in a 30.3 percent response rate. This volunteer sample was predominantly female (74.0\%), which is slightly higher than the study population of 69.0 percent. The average age of students was 36.1 years, and 8.6 percent of students were traditional-aged students, 19 to 22 years; 20.1 percent were 23 to 29 ; 36.2 percent were 30 to 39; 25.3 percent were 40 to 49 ; and 9.9 percent of students were age 50 to 72 years. The majority of students responding (51.5\%) had entered the university within the past year, and 46.5 percent of students reported having had previous distance learning experience.

\section{Factor Analysis}

Suitability of factor analysis for both scales of the questionnaire was first examined (see Appendix Tables A1 and A4). Bartlett's test of sphericity was significant for both scales, indicating the original correlation matrix was not an identity matrix. Kaiser-Meyer-Oklin Measure of Sampling Adequacy (KMO) levels were considered to be "good" for both scales according to Kaiser's (1975) criteria, indicating that the patterns of correlation between the items were fairly tight; therefore, factor analysis should result in distinct and reliable factors.

A separate factor analysis was performed on each of the two scales in the questionnaire, utilizing the maximum likelihood method of extraction and an Oblique rotation, Direct Oblimin (see Appendix Tables A2 and A3 for questionnaire items and their loadings). Based on the Eigenvalues over 1.0 rule, visual inspection of the scree plot, and interpretability, the following factors were identified in each scale (see Tables 2 and 3). Item loadings less than 0.3 have been excluded for clarity, except for Item 16, "I have trouble using the computer when I study," which was allowed to stay in the factor due to its conceptual match with the other items and Stevens' (1992) research showing that, with large samples over $N=300$, item loadings under 0.3 can be considered statistically significant. 
Bray, Aokyi \& Dlugosh

Table 2. Factor reliability of the opinions of Distance Learning Scale

\begin{tabular}{|l|c|c|c|}
\hline \multicolumn{1}{|c|}{ Factors } & $\begin{array}{l}\text { Number of Items in } \\
\text { Factor }\end{array}$ & $\begin{array}{l}\text { Cronbach's } \\
\text { Alpha }\end{array}$ & $\begin{array}{l}\text { Variance } \\
\text { Percentage } \\
\text { Explained }\end{array}$ \\
\hline $\begin{array}{l}\text { Meeting } \\
\text { Independent Study } \\
\text { Challenges }\end{array}$ & 6 & .749 & 30.60 \\
\hline $\begin{array}{l}\text { Ease of Student } \\
\text { Interaction }\end{array}$ & 3 & .774 & 10.28 \\
\hline $\begin{array}{l}\text { Course Clarity } \\
\text { Ease of Teacher } \\
\text { Interaction }\end{array}$ & 2 & .685 & 7.72 \\
\hline $\begin{array}{l}\text { Ease of Computer } \\
\text { Interaction }\end{array}$ & 3 & .739 & 6.14 \\
\hline
\end{tabular}

Table 3. Factor reliability of the General Learning Preferences Scale

\begin{tabular}{|l|c|c|c|}
\hline \multicolumn{1}{|c|}{ Factors } & $\begin{array}{l}\text { Number of Items } \\
\text { in Factor }\end{array}$ & $\begin{array}{l}\text { Cronbach's } \\
\text { Alpha }\end{array}$ & $\begin{array}{l}\text { Variance } \\
\text { Percentage } \\
\text { Explained }\end{array}$ \\
\hline $\begin{array}{l}\text { Preference for } \\
\text { Course Clarity }\end{array}$ & 4 & .761 & 34.2 \\
\hline $\begin{array}{l}\text { Preference for } \\
\text { Social Interaction }\end{array}$ & 4 & .750 & 24.2 \\
\hline
\end{tabular}

The exploratory factor analysis indicated that, in general, items tended to load together into the factors they were designed to measure. In the Opinions of Distance Learning Scale, one exception was the Student Autonomy variable, which was found to be too broadly defined. One Student Autonomy item did not load with any other factor and was thus omitted from the factor analysis, and another item loaded with the two Computer Interaction items. Two Student Autonomy items, however, did load together with items from other variables that concerned the challenges of independent study, specifically, difficulties with course clarity and isolation. Since students tended to disagree that these difficulties were a problem for them, the factor was given the name Meeting Independent Study Challenges. In the General Learning Preferences Scale, because of the small number of items, only two factors emerged: Preference for Course Clarity and Preference for Social Interaction.

\section{Student Satisfaction Results}

Research Question 1: In general, how satisfied were students with their learning in this online distance education program?

The average mean of the two items designed to measure student Learning Satisfaction was 3.97, indicating that students were satisfied overall with their learning in this distance 
learning program. It should be noted that none of the 422 students strongly disagreed with Item 10 (see Table 4).

Table 4. Student learning satisfaction item

\begin{tabular}{|l|c|c|c|c|c|}
\hline Item & Number & Minimum & Maximum & $\begin{array}{c}\text { Standard } \\
\text { Deviation }\end{array}$ & Mean \\
\hline Item 10 & 422 & 2 & 5 & .757 & 4.01 \\
\hline $\begin{array}{l}\text { Item 21 } \\
\text { (reversed) }\end{array}$ & 421 & 1 & 5 & .885 & 3.93 \\
\hline Items 10 \& 21 & 419 & 1.5 & 5 & .695 & 3.97 \\
\hline
\end{tabular}

Research Question 2: To what extent was student learning satisfaction predicted by a regression model containing the questionnaire subscales, and the demographic variables?

In order to answer this research question, a simultaneous multiple regression was performed to determine the relationship between: (1) factors (aggregating the variable scores for each item in the factor into subscales), (2) demographic variables, and (3) the two indicators of student satisfaction (Items 10 and 21). Five significant predictors of learning satisfaction were found (see Table 5).

Table 5. Significant predictors of Learning Satisfaction

\begin{tabular}{|l|l|}
\hline \multicolumn{1}{|c|}{ Predictor Name } & \multicolumn{1}{c|}{$\begin{array}{c}\text { Student Satisfaction } \\
\text { Item Number }\end{array}$} \\
\hline Meeting Independent Study Challenges & Item 10 and Item 21 \\
\hline Ease of Computer Interaction & Item 10 \\
\hline Ease of Teacher Interaction & Item 10 \\
\hline Preference (-) for Social Interaction in Learning & Item 10 \\
\hline 2006 (recent) entry & Item 21 \\
\hline
\end{tabular}

\section{Multiple Regression Results - Item 10}

Item 10 showed significant results for three of the opinions of distance learning subscales: Meeting Independent Study Challenges, Ease of Computer Interaction, and Ease of Teacher Interaction, and one of the General Learning Preference subscales, Preference for Social Interaction in Learning. Overall, the regression model was significantly different from the null model (i.e., no predictor model) $(F(15,298)=11.81$, p < .001) (see Appendix Table A6). None of the demographic variables, however, were found to be statistically significant predictors of student learning satisfaction. This finding was consistent with Hiltz and Shea's (2005) observation that "demographic characteristics, such as age and gender, are weak predictors of success in ALNs" (asynchronous learning networks) compared to pedagogical factors (p. 154). Individual predictors are discussed below. 
Predictor (1) Meeting Independent Study Challenges - Students who found it easy to persevere in the face of the challenges of independent study were more satisfied with their learning than those who did not $(b=.273, \mathrm{t}(313)=4.14, \mathrm{p}<.001)$. This indicated that for every 1-unit increase in the Meeting the Challenges of Independent Study subscale, student learning satisfaction increased by .273 units, holding all other predictors constant. This was the strongest predictor of student satisfaction and the only significant predictor of learning satisfaction found with both learning satisfaction items. This subscale contains two items originally designed to measure student autonomy and, combined with the other items in this factor, points to the importance of maintaining perseverance in the face of distance learning challenges - supporting studies which found the personal quality of perseverance to be a success factor in distance learning (Osborn, 2001; Mielke, 1999).

Predictor (2) Ease of Computer Interaction - Students who found it easy to use computers were more satisfied with their learning than those who did not $(b=.271, t(313)=4.26, p<$ .001). This indicated that for every 1-unit increase in the Ease of Computer Interaction subscale, student learning satisfaction increased by .222 units, holding all other predictors constant. This finding supports other studies (Miller, Rainer \& Corley, 2003; Schrum \& Hong, 2001) that found a positive relationship between student comfort with technology and student success and satisfaction in online courses.

Predictor (3) Ease of Teacher Interaction - Students who found it easy to interact with instructors were more satisfied with their learning than those who did not $(b=.145, t(313)$ $=2.39, p=.017)$. This indicated that for every 1-unit increase in the Teacher Interaction subscale, student learning satisfaction increased by .145 units, holding all other predictors constant. Of the seven subscales, this subscale had the second highest correlation with Item $10(r=.455)$. In fact, the questionnaire item that had the highest correlation with student satisfaction as measured by Item $10(r=.425)$ wasItem 6: "It is easy to ask my teachers questions about assignments." This finding supports studies (Chen \& Willits, 1998; Fredericksen et al, 2000; Marks, Sibley \& Arbaugh, 2005) that found interaction with the teacher to be an important predictor of perceived learning in distance learning programs.

Predictor (4) Preference (-) for Social Interaction in Learning - Students who did not prefer social interaction when learning were more satisfied with their learning than those who did $(b=-.126, t(313)=-2.36, p<.019)$. This indicated that for every 1-unit increase in the Preference for Social Interaction in Learning subscale, student learning satisfaction decreased by .126 units, holding all other predictors constant. This is consistent with the low mean finding of 2.45 for the Ease of Student-Interaction subscale, which was the only subscale mean lower than the neutral point of 3.0 found in this study (see Appendix Table A5.). Clearly, having a preference for an aspect of learning that is difficult to obtain in a particular learning context would lead to less satisfaction. This finding also supports other studies (Kelsey \& D’souza, 2004; Swan, 2001) which found that student interaction did not play an important role in student satisfaction.

\section{Multiple Regression Results - Item 21}

With the second item used to measure learning satisfaction, Item 21, the resulting regression model differed significantly from the null model (i.e., no predictor model) $(F=$ $(15,300)=6.198, p=.001$ ) (see Appendix Table A6). This item revealed a significant result for one of the Opinions of Distance Learning subscales, Meeting Independent Study 
Challenges $(b=.458, t(315)=5.54, p<.001)$, discussed above as Predictor $(1)$ for Item 10 . There was also a significant result for one of the demographic variables, Year of Entry.

Predictor (5) Year of Entry - Fall 2006 - Being a Fall 2006 entrant, compared to three other groups - Spring 2006 entrants, 2005 entrants, and 2004 entrants - led to increases of .258 point on Item 21 after controlling all the other predictors $(b=.258, \mathrm{t}(315)=2.04, \mathrm{p}=$ .042). For Fall 2006 entrants, student learning satisfaction increased by .258 units, holding all other predictors constant, indicating there is a "honeymoon" period of increased learning satisfaction for the most recent entrants to this program.

\section{Qualitative Results}

A separate qualitative analysis was performed on the 840 student responses to the three open-ended items used in the questionnaire. The strongest themes that emerged are described below (see Table 6).

Table 6. Strongest qualitative themes

\begin{tabular}{|l|l|l|}
\hline $\begin{array}{l}\text { Advantages of Distance } \\
\text { Learning }\end{array}$ & $\begin{array}{l}\text { Difficulties of Distance } \\
\text { Learning }\end{array}$ & $\begin{array}{l}\text { General Learning } \\
\text { Preferences }\end{array}$ \\
\hline $\begin{array}{l}\text { 1. The Importance of } \\
\text { Personal Convenience } \\
\text { (69.3\% of responses in } \\
\text { category) }\end{array}$ & $\begin{array}{l}\text { 1. Difficulties with } \\
\text { Motivation and Time } \\
\text { Management (32.2\%) }\end{array}$ & $\begin{array}{l}\text { 1. Preference for Study } \\
\text { Alone (23.2\%) }\end{array}$ \\
\hline & $\begin{array}{l}\text { 2. Difficulties with Teacher } \\
\text { Interaction (19.2\%) }\end{array}$ & \\
\hline & $\begin{array}{l}\text { 3. Difficulties with Student } \\
\text { Interaction (15.6\%) }\end{array}$ & \\
\hline & $\begin{array}{l}\text { 4. Difficulties with Course } \\
\text { Materials (9.2\%) }\end{array}$ & \\
\hline & & \\
\hline
\end{tabular}

\section{Theme 1 - The Importance of Personal Convenience}

The largest number of student responses (69.3\%) regarding the advantages of distance learning concerned the convenience of being able to study at times and places of students' choosing. Responses such as these were common:

"I can adjust study to my lifestyle and study at my own pace."

"Because of work it is very difficult for me to attend school, so this school is very helpful."

"It is convenient to study when you have a break from childrearing duties." 


\section{Theme 2 - Difficulties with Motivation and Time Management}

The largest number of responses (32.7\%) was in regard to the difficulties of distance learning, specifically, the difficulty of setting some kind of regular study schedule and having the motivation to maintain it. This complements Theme 1 , as the Personal Convenience of choosing the time and place of study implies individual responsibility for making sure the study gets done. Many students reported difficulty setting a regular study schedule and having the motivation to maintain it. Responses such as these were common:

"It is hard to stick to a regular schedule when work and everyday life interrupts."

"It takes a strong motivation to stick to a study schedule, especially at home."

\section{Theme 3 - Difficulties with Teacher Interaction}

Also in regard to the difficulties of distance learning, a substantial number of responses (19.2\%) concerned the difficulties of interacting with the teacher in an online program. Responses such as these were common:

"When communicating with the teacher online a human element lacking."

"It is difficult to communicate with the teachers. They are slow to answer my email."

\section{Theme 4 - Difficulties with Student Interaction}

A smaller number of responses (15.6\%) in regard to difficulties of distance learning dealt with students' difficulties interacting with other students. Responses like these were common:

"Making friends is difficult. When you attend a traditional school, you can meet people your own age. Via the Internet it is difficult to connect or feel an affinity with others."

"If one can make a friend we can mutually raise the motivation."

Difficulties with social interaction were not only important in the affective realm; it was also difficult for many students to clarify understanding when course materials were difficult to understand. Responses like these were common:

"Especially when problems come up with study, there is a lack of friends to discuss with"

\section{Theme 5 - The Importance of Course Clarity}

Difficulties with the clarity of course materials were specifically mentioned in 9.6 percent of student responses, and underlined the importance of course clarity as a facilitator of 
Bray, Aokyi \& Dlugosh

independent study. Many comments mentioned that difficulties understanding content lead to inertia and trouble maintaining a study schedule. For example, one student wrote:

"It is difficult to be sure you are understanding the text, which causes uneasiness when studying alone. It becomes difficult to move forward with study."

\section{Theme 6 - Preference for Study Alone}

In regard to student general learning preferences (Item 31), the largest number of student responses concerned the preference for study alone, and 23 percent of students mentioned this idea in their responses. Responses such as this were common:

"I prefer to study alone and quietly."

The idea of studying alone, however, was often combined with preferences for other modes of learning. For example:

"First I like to read alone and try to understand as best as possible, then I like to check my understanding with my teacher."

\section{Discussion}

In this section, the quantitative and qualitative results are converged and discussed. The first research question concerned the overall level of learning satisfaction, and the high level of learning satisfaction in the sample indicated that this university attracts students suited to the demands and opportunities presented by this learning context. These results differ from Kubota and Fujikawa's (2007) findings where traditional Japanese undergraduates taking an experimental online distance learning course were reticent to recommend the course to friends. The reason for this difference is not possible to determine; however, program characteristics, student age, motives to enter, and the fact that students in this online distance university self-selected the distance mode of study are all possible factors.

The second research question sought to determine the predictors of learning satisfaction, and three of the five predictors emerging from the quantitative analysis, emphasized the importance of personal factors internal to the learner for learning satisfaction in this educational context: (1) Meeting Independent Study Challenges stressed the personal ability to persevere in the face of distance learning challenges such as unclear content and isolation, (2) Ease of Computer Interaction stressed personal ability with computers, and (3) Preference for Social Interaction in Learning (which was negatively correlated with learning satisfaction) suggested a preference for independent learning. The importance of personal factors to learning satisfaction was supported by the qualitative results which found that three of the strongest themes - (1) The Importance of Personal Convenience, (2) Difficulties with Motivation and Time Management, and (3) The Preference for Studying Alone - also emphasized the importance of personal factors for students in this learning program. To a large extent, these results reflect the nature of the program and its demands for independent study. 
Bray, Aokyi \& Dlugosh

The other important predictor of student learning satisfaction emerging from the quantitative analysis was Ease of Teacher Interaction. This was not surprising as studies have found interaction with the teacher to be important to learners in face-to-face classes (Chickering \& Gamson, 1987), in distance learning contexts (Marks, Sibley \& Arbaugh, 2005; Fredericksen et al., 2000; Chen \& Willits, 1998) and in Japan where a teachercentered approach to learning and appreciation of authority figures is common (Kubota \& Fujikawa, 2007; Hadley \& Hadley, 1996). Clearly, it is a challenge to provide large numbers of students with opportunities for interaction with the teacher at a distance. The learning system at this university, which allows for synchronous and asynchronous viewing of lectures as well as communication with the teacher via the Internet, is an attempt to meet student needs in a cost-effective manner. The qualitative results supported the importance of this predictor, as Difficulties with Teacher Interaction emerged as a strong theme in the analysis of student comments.

The findings for the Course Clarity were neutral in the prediction model; however, the qualitative data made it clear that Course Clarity was important to students because it facilitated independent study. Ease of Student Interaction was also neutral in the prediction model, yet the qualitative responses indicated that Student Interaction is a polarized issue, as some students clearly preferred to work independently of others, while others clearly wished for more interaction with other students in order to clarify understanding or reduce the sense of isolation. It should be noted that professors at this university do not typically require students to work together on projects or ask them to engage in online asynchronous threaded discussions as is common in other distance learning programs. It is interesting to consider whether greater personal experience with a "constructivist" mode of learning would convince students of the benefits of student interaction in learning. The qualitative responses, however, indicated students may need both encouragement to interact online and support in developing skills for interaction in a "low context" online environment where information about others’ age, gender, social status, and interests, are less salient.

\section{Limitations and Recommendations for Further Study}

One limitation of this study was that it was a volunteer sample of students, and the results could only suggest the characteristics of the study population. In regard to questionnaire development, researchers' access to students was limited due to privacy concerns, and although measures were taken to increase validity and reliability of the instrument, a more robust pilot process would have been preferable. In particular, further work will be necessary to improve the focus of items designed to measure Student Autonomy.

In regard to further study, the results suggest many similarities with adult learners from other countries however, to make definitive statements about cultural similarities or differences, it would be necessary to do a comparison study with learners from other countries.

\section{Conclusions}

The results of this study indicated this online distance university differs from other undergraduate institutions in Japan, because it attracts predominantly older "nontraditional” learners who have often chosen to enroll because of convenience or because there are no other viable options due to physical distance from universities or work/ 
domestic responsibilities. The high level of student satisfaction in the sample indicated that this university attracts students better suited to the demands of this learning context.

The mode of instruction at this university follows a predominantly transmission model emphasizing independent study. This learning context, therefore, was more satisfying for independent, computer-competent learners who could persevere in the face of the challenges presented by this program, while being able to take advantage of the opportunities provided for interaction with the teacher. Opportunities for interaction with other students were available but not emphasized, and as some students indicated a preference for more social interaction when learning, this is an area where program development could take place. The study results suggest that "getting the mix right" for Japanese online distance learners must entail being careful to provide ample opportunities for interaction with the teacher, while assuming students have the necessary autonomy to study on their own, as long as course materials are clearly presented.

Note: The complete study including a review of research on Japanese learners can be found in the book Japanese Online Distance Education: Learners' Perspectives, by Eric Bray, VDM Publishing, May 2008.

\section{References}

Anderson, T. (2003). An updated theoretical rationale for interaction. The International Review of Research in Open and Distance Learning, 9(2). http://it.coe.uga.edu/itforum/paper63/paper63.htm

Association for Private University Correspondence Education. (2006). Overview of university correspondence education. http://www.uce.or.jp/WHATisUCE.html

Chen, Y., \& Willits, F. (1998). A path analysis of the concepts in Moore's theory of transactional distance in a videoconferencing learning environment. Journal of Distance Education, 13(2), 1-21.

Chickering, A. W., \& Gamson, Z. F. (1987). Seven principles for good practice in undergraduate education. AAHE Bulletin. http://www.csuhayward.edu/wasc/pdfs/End\%20Note.pdf

Creswell, J. (2003). Research design: Qualitative, quantitative, and mixed methods approaches. Thousand Oaks: Sage Publications.

Creswell, J., \& Plano Clark, V. (2007) Designing and conducting mixed methods design and research. Thousand Oaks, CA: Sage Publications.

Economist Intelligent Unit \& IBM (2003). The e-learning readiness rankings. http://graphics.eiu.com/files/as_pdfs/eReady 2003.pdf

Fredericksen, E., Pickett, A., Shea, P., Pelz, W., \& Swan, K. (2000). Student satisfaction and perceived learning with on-line courses: Principles and examples from the SUNY Learning Network. Journal of Asynchronous Learning Networks, 4(2), http://www.sloan-c.org/publications/jaln/v4n2/v4n2_fredericksen.asp 
Garrison, D. R., \& Shale, D. (1987). Mapping the boundaries of distance education: Problems in defining the field. The American Journal of Distance Education, 1(1), 4-13.

Gunawardena, C., Nolla, A. C., Wilson, P. L., Lopez-Islas, J. R., Ramirez-Angel, N., \& Megchum-Alpizar, R. M. (2001). A cross-cultural study of group process and development in online conferences. Distance Education, 22(1), 85-121.

Hadley, G., \& Hadley, H. (1996). The culture of learning and the good teacher in Japan: An analysis of student views. The Language Teacher, 20(9), 53-55.

Hillman, D. C. A., Willis, D., J., \& Gunawardena, C. N. (1994). Learner-interface interaction in distance education: An extension of contemporary models and strategies for practitioners. American Journal of Distance Education, 8(2), 30-42.

Hiltz, S. R., \& Shea, P. (2005). The student in the online Classroom. In S. Hiltz \& R. Goldman (Eds.), Learning together online: Research on asynchronous learning networks, (pp. 145-168). Mahwah, NJ: Erlbaum.

Hofstede, G. (1986). Cultural differences in teaching and learning. International Journal of Intercultural Relations, 10(4), 301-320.

Jin, L. \& Cortazzi, M. (1998). Dimensions of dialog: Large classes in China. International Journal of Educational Research, 29(8), 739-761.

Jung, I., \& Suzuki, K. (2006). Blended learning in Japan and its application in liberal arts education. In C. Bonk and C. Graham (Eds.) The handbook of blended learning. (pp. 267-280). San Francisco: John Wiley \& Pfeiffer.

Kaiser, H. F. (1974). An index of factorial simplicity. Psycometrika, 35, 401-415.

Kelsey, K., \& D’souza, A. (2004). Student motivation for learning at a distance: Does interaction matter? Online Journal of Distance Learning Administration, 7(2), http://www.westga.edu/ distance/jmain11.html

Kubota, K., \& Fujikawa, K. (2007). Online distance teaching of undergraduate finance: A case for Musashi University and Konan University, Japan. International Review of Research in Open and Distance Learning, 8(1). http://www.irrodl.org/index.php/irrodl/article/view/261/780

Marks, R., Sibley, S., \& Arbaugh, J. B. (2005). A structural equation model on predictors for effective online learning. Journal of Management Education, 29(4) 531-563.

McCarty, S. (1999). Japanese Culture Meets Online Education. EDUCAUSE: Educom Review, 34 (3), 42-44.

Mielke, D. (1999). Effective teaching in Distance Education. Washington DC: Office of Educational Research and Improvement. (ERIC Document Reproduction Service No. ED 436 528) 
Bray, Aokyi \& Dlugosh

Miller, M., Rainer, K. R., \& Corley, K.J. (2003). Predictors of engagement and participation in an online course. Online Journal of Distance Learning Administration, 4(1). http://www.westga.edu/ distance/ojdla/spring61/miller61.htm

MEXT (2006). Formal Education. http://www.mext.go.jp/english/org/f formal 22.htm

MEXT (2007). Gakko Kihon Chousa Sokuhou [Brief Report of School Basic Survey]. http://www.mext.go.jp/b_menu/toukei/001/07073002/004/001.pdf

Moore, M. (2006). Questions of culture. The American Journal of Distance Education, 20(1), 1-5.

Moore, M. (1989). Three types of interaction. The American Journal of Distance Education, 3(2), 1-7.

Moore, M. (1972). Learner autonomy: The second dimension of independent learning. Convergence, 5(2), 76-88.

Moore, M., \& Kearsley, G. (2005). Distance education: A systems view. Belmont, CA: Wadsworth.

Morse, K. (2003). Does one size fit all? Exploring asynchronous learning in a multicultural environment. Journal of Asynchronous Learning, 7(1). http://sloanc.org/publications/jaln/v7n1/pdf/v7n1_morse.pdf

OECD (2007). Education at a Glance. http://www.oecd.org/dataoecd/4/55/39313286.pdf

Osborn, V. (2001). Identifying at-risk students in video conferencing and Web-based distance education. The American Journal of Distance Education, 15(1), 41-54.

Russell, T. L. (1999). The no significant difference phenomenon. Office of Instructional Telecommunications. Raleigh, NC: North Carolina State University.

Schrum, L., \& Hong, S. (2001). The potential for electronic educational environments: Ensuring student success. Paper presented at the 2001 Annual Meeting of the American Educational Research Association, Seattle, WA.

Stein, D., Wanstreet, C., Calvin, J., Overtoom, C., \& Wheaton, J. (2005). Bridging the transactional distance gap in online learning environments. American Journal of Distance Education, 19(2), 105-118.

Stevens, J. (1992) Power of multivariate statistics for the social sciences. (2nd Edition). Hillsdale, NJ: Erlbaum

Swan, K. (2001). Virtual interaction: Design factors affecting student satisfaction and perceived learning in asynchronous online courses. Distance Education, 22(2), 306-331. 
Swan, K. (2004). Learning online: current research on issues of interface, teaching presence and learner characteristics. In J. Bourne \& J. Moore (Eds.) Elements of quality online education, into the mainstream (pp. 63-79). Needham, MA: Sloan Center for Online Education.

\section{Appendices}

Table A1. Obliquely rotated component loadings of items in Opinions of Distance Learning Scale

\begin{tabular}{|c|c|c|c|c|c|}
\hline $\begin{array}{l}\text { Questionnaire Items } \\
\mathbf{N}=\mathbf{3 6 8} \text { (excluded cases } \\
\text { listwise) } \\
\text { 18. It is difficult to get } \\
\text { motivated to do my } \\
\text { assignments. (R) }\end{array}$ & $\begin{array}{l}\begin{array}{l}\text { Factor } \\
\text { One } \\
\text { (MC) }\end{array} \\
-.736\end{array}$ & $\begin{array}{l}\text { Factor } \\
\text { Two } \\
\text { (SI) }\end{array}$ & $\begin{array}{l}\text { Factor } \\
\text { Three } \\
\text { (CC) }\end{array}$ & $\begin{array}{l}\text { Factor } \\
\text { Four } \\
\text { (TI) }\end{array}$ & $\begin{array}{l}\text { Factor } \\
\text { Five } \\
\text { (CI) }\end{array}$ \\
\hline $\begin{array}{l}\text { 19. It is difficult to understand } \\
\text { the goals of my courses. (R) }\end{array}$ & -.701 & & & & \\
\hline $\begin{array}{l}\text { 14. It is difficult to understand } \\
\text { how to do my assignments. (R) }\end{array}$ & -.573 & & & & \\
\hline $\begin{array}{l}\text { 20. I feel isolated from other } \\
\text { students. (R) }\end{array}$ & -.495 & & & & \\
\hline $\begin{array}{l}\text { 12. I have trouble finding time } \\
\text { to do assignments. (R) }\end{array}$ & -.406 & & & & \\
\hline $\begin{array}{l}\text { 13. It takes a long time to get } \\
\text { comments on assignments back } \\
\text { from teachers ( } \mathrm{R} \text { ) }\end{array}$ & -.354 & & & & \\
\hline $\begin{array}{l}\text { 9. It is easy to get to know other } \\
\text { students. }\end{array}$ & & .788 & & & \\
\hline $\begin{array}{l}\text { 4. It is easy to exchange } \\
\text { opinions with other students } \\
\text { about the course. }\end{array}$ & & .704 & & & \\
\hline $\begin{array}{l}\text { 15. It is difficult to develop } \\
\text { relationships with other } \\
\text { students. (R) }\end{array}$ & & -.663 & & & \\
\hline
\end{tabular}


3. Course assignments are easy to understand.

7. Courses are well-organized.

6. It is easy to ask the teacher questions about assignments.

2. It is easy to get guidance from my teacher.

17. It is difficult to feel close to my teacher. (R)

5. It is good I can study using the computer.

8. It is good I can make decisions about what I learn.
.536

.384

16. I have trouble using the computer when I study. (R)

Note. $M C=$ Meeting Independent Study Challenges, SI = Ease of Student Interaction, CC = Course Clarity, $T I=$ Ease of Teacher Interaction \& CI = Ease of Computer Interaction, $(R=$ reversed scoring)

Table A2. Obliquely rotated component loadings of the items in the General Learning Preferences Scale

\section{Questionnaire Items}

$\mathbf{N}=\mathbf{4 0 1}$ (Excluded cases listwise)

30. I prefer a course where the assignments are clear.

26. It suits me to study in a course where the course materials are easy to understand.

28. I prefer to be able to make decisions about what I learn

29. I prefer to get guidance from my teacher when I

$\begin{array}{ll}\text { Factor } 1 & \text { Factor } 2 \\ \text { PCC } & \text { PSI }\end{array}$
learn. 
24. It suits me to communicate with other students when I study.

27. I prefer to interact with other students when I learn.

23. It suits me to study independently. (R)

25. It suits me to communicate with my teacher when I study.

Note. PCC = Preference for Course Clarity, PSI = Preferences for Social Interaction, $(R=$ reversed scoring)

Table A3. KMO and Bartlett's Test for Suitability for Factor Analysis

\begin{tabular}{|c|c|c|c|c|}
\hline & \multicolumn{4}{|c|}{ Tests of Suitability for Factor Analysis } \\
\hline \multirow[t]{2}{*}{$\begin{array}{l}\text { Questionnaire } \\
\text { Scales }\end{array}$} & $\begin{array}{l}\text { Bartlett's } \\
\text { Test of } \\
\text { Sphericity }\end{array}$ & $\begin{array}{l}\text { Kaiser- } \\
\text { Meyer- } \\
\text { Oklin } \\
\text { Measure of } \\
\text { Sampling } \\
\text { Adequacy } \\
\text { (KMO) }\end{array}$ & & \\
\hline & & $\begin{array}{c}\text { Approx. } \\
\text { Chi-Square }\end{array}$ & df & Sig. \\
\hline $\begin{array}{l}\text { Opinions of } \\
\text { Distance } \\
\text { Learning Scale } \\
\text { General }\end{array}$ & .862 & 2020.5 & 153 & $<.001$ \\
\hline $\begin{array}{l}\text { Learning } \\
\text { Preferences } \\
\text { Scale }\end{array}$ & .735 & 823.9 & 28 & $<.001$ \\
\hline
\end{tabular}


Table A4. Factor Correlation Matrix

\section{Correlations Between Factor Subscales}

\begin{tabular}{|c|c|c|c|c|c|c|c|c|}
\hline Subscales & & $\mathrm{MC}$ & SI & $\mathrm{CC}$ & $\mathrm{TI}$ & CI & PCC & PSI \\
\hline MC & $\begin{array}{l}\text { Pearson } \\
\text { Correlation }\end{array}$ & 1 & $.334 * *$ & $.441 * *$ & $.543^{* *}$ & $.374^{* *}$ & -.065 & $-225^{* *}$ \\
\hline $\begin{array}{l}\text { Meeting } \\
\text { Challenges }\end{array}$ & $\begin{array}{l}\text { Sig. } \\
\text { tailed) }\end{array}$ & . & .000 & .000 & .000 & .000 & .200 & .000 \\
\hline $\begin{array}{l}\text { of } \\
\text { Distance } \\
\text { Learning }\end{array}$ & $\mathrm{N}$ & 406 & 394 & 398 & 394 & 394 & 396 & 397 \\
\hline SI & $\begin{array}{l}\text { Pearson } \\
\text { Correlation }\end{array}$ & $.334 * *$ & 1 & $.393 * *$ & $.503 * *$ & $.136^{* *}$ & $-.128 *$ & -.080 \\
\hline $\begin{array}{l}\text { Ease of } \\
\text { Student }\end{array}$ & $\begin{array}{l}\text { Sig. } \\
\text { tailed) }\end{array}$ & .000 & . & .000 & .000 & .007 & .011 & .110 \\
\hline Interaction & $\mathrm{N}$ & 394 & 409 & 403 & 397 & 397 & 397 & 400 \\
\hline CC & $\begin{array}{l}\text { Pearson } \\
\text { Correlation }\end{array}$ & $.441^{* *}$ & $.393 * *$ & 1 & $.580 * *$ & $.373 * *$ & .081 & -.070 \\
\hline $\begin{array}{l}\text { Course } \\
\text { Clarity }\end{array}$ & $\begin{array}{l}\text { Sig. } \\
\text { tailed) }\end{array}$ & .000 & .000 & . & .000 & .000 & .103 & .158 \\
\hline & $\mathrm{N}$ & 398 & 403 & 414 & 402 & 402 & 401 & 406 \\
\hline TI & $\begin{array}{l}\text { Pearson } \\
\text { Correlation }\end{array}$ & $.543^{* *}$ & $.503 * *$ & $.580 * *$ & 1 & $.380 * *$ & .009 & $\begin{array}{l}- \\
.130 * *\end{array}$ \\
\hline $\begin{array}{l}\text { Ease of } \\
\text { Teacher }\end{array}$ & $\begin{array}{l}\text { Sig. } \\
\text { tailed) }\end{array}$ & .000 & .000 & .000 & . & .000 & .860 & .009 \\
\hline Interaction & $\mathrm{N}$ & 394 & 397 & 402 & 410 & 397 & 399 & 399 \\
\hline CI & $\begin{array}{l}\text { Pearson } \\
\text { Correlation }\end{array}$ & $.374^{* *}$ & $.136 * *$ & $.373^{* *}$ & $.380 * *$ & 1 & $.163^{* *}$ & -.017 \\
\hline $\begin{array}{l}\text { Ease of } \\
\text { Computer }\end{array}$ & $\begin{array}{l}\text { Sig. } \\
\text { tailed) }\end{array}$ & .000 & .007 & .000 & .000 & . & .001 & .739 \\
\hline Interaction & $\mathrm{N}$ & 394 & 397 & 402 & 397 & 409 & 397 & 401 \\
\hline PCC & $\begin{array}{l}\text { Pearson } \\
\text { Correlation }\end{array}$ & -.065 & $-.128 *$ & .081 & .009 & $.163^{* *}$ & 1 & $.188^{* *}$ \\
\hline $\begin{array}{l}\text { Preference } \\
\text { for Course }\end{array}$ & $\begin{array}{l}\text { Sig. } \\
\text { tailed) }\end{array}$ & .200 & .011 & .103 & .860 & .001 & . & .000 \\
\hline Clarity & $\mathrm{N}$ & 396 & 397 & 401 & 399 & 397 & 411 & 401 \\
\hline PSI & $\begin{array}{l}\text { Pearson } \\
\text { Correlation }\end{array}$ & $.225 * *$ & -.080 & -.070 & $.130 * *$ & -.017 & $.188^{* *}$ & 1 \\
\hline $\begin{array}{l}\text { Preference } \\
\text { for Social }\end{array}$ & $\begin{array}{l}\text { Sig. } \\
\text { tailed) }\end{array}$ & .000 & .110 & .158 & .009 & .739 & .000 & . \\
\hline $\begin{array}{l}\text { Interaction } \\
\text { in } \\
\text { Learning }\end{array}$ & $\mathrm{N}$ & 397 & 400 & 406 & 399 & 401 & 401 & 413 \\
\hline
\end{tabular}

Note. $* *=$ Correlation is significant at the 0.01 level (2-tailed).

$*=$ Correlation is significant at the 0.05 level (2-tailed) 
Bray, Aokyi \& Dlugosh

Table A5. Descriptive data - subscale means and standard deviation

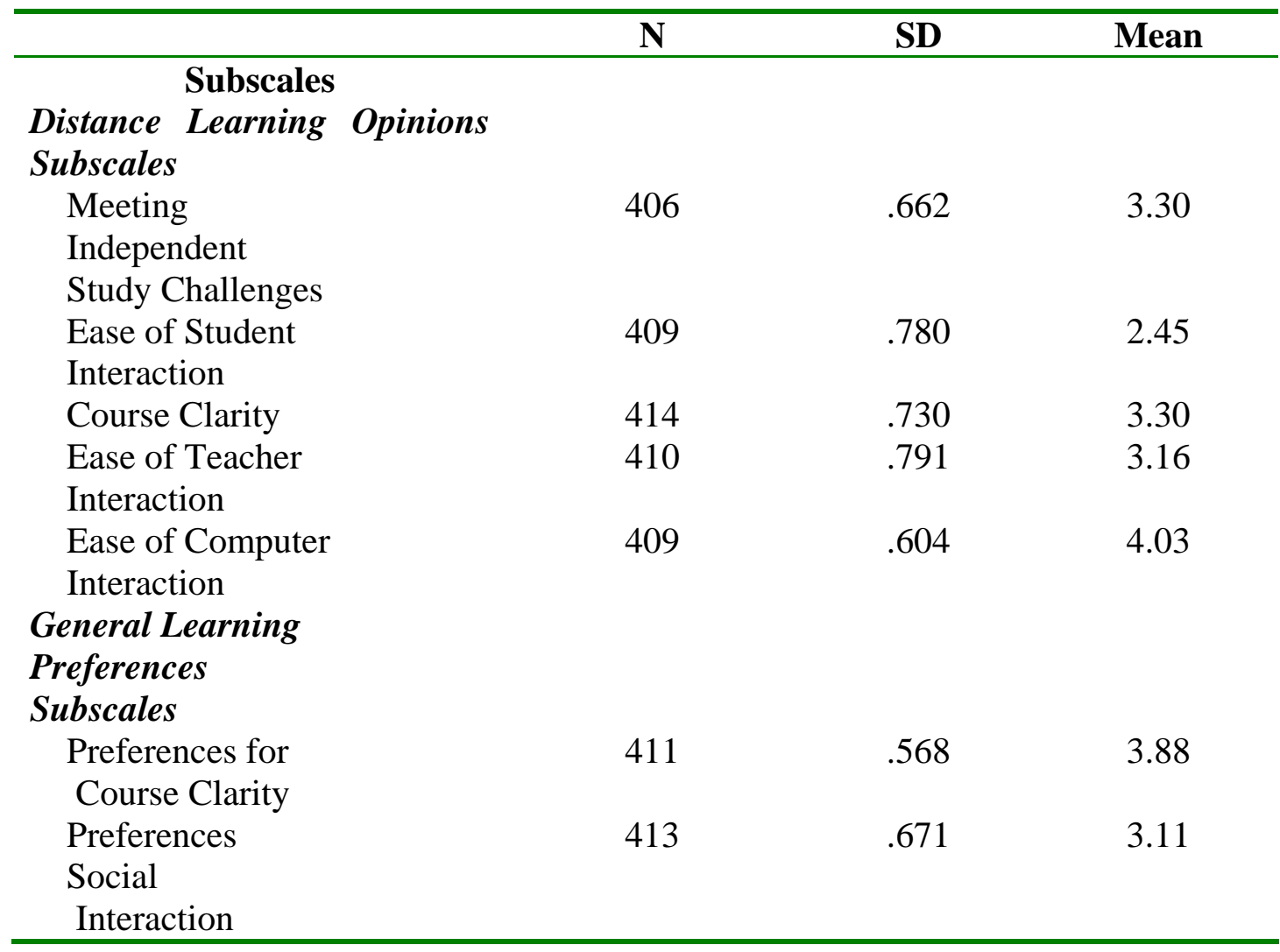


Table A6. Multiple regression - coefficients (Item 10)

\begin{tabular}{|c|c|c|c|c|c|c|}
\hline & & $\begin{array}{c}\text { Unstandardized } \\
\text { Coefficients }\end{array}$ & & $\begin{array}{l}\text { Standardized } \\
\text { Coefficients }\end{array}$ & $\mathrm{t}$ & Sig. \\
\hline Model & & $\mathrm{B}$ & $\begin{array}{l}\text { Std. } \\
\text { Error }\end{array}$ & Beta & & \\
\hline \multirow[t]{16}{*}{1} & (Constant) & 1.10 & .386 & & 2.87 & .004 \\
\hline & $\begin{array}{l}\text { Motivation } \\
\text { Challenges }\end{array}$ & .273 & .066 & .244 & 4.14 & .000 \\
\hline & $\begin{array}{l}\text { Student } \\
\text { Interaction }\end{array}$ & .007 & .050 & .074 & 1.34 & .181 \\
\hline & $\begin{array}{l}\text { Course } \\
\text { Clarity }\end{array}$ & .009 & .061 & .089 & 1.45 & .148 \\
\hline & $\begin{array}{l}\text { Teacher } \\
\text { Interaction }\end{array}$ & .145 & .061 & .154 & 2.39 & .017 \\
\hline & $\begin{array}{l}\text { Computer } \\
\text { Interaction }\end{array}$ & .271 & .064 & .222 & 4.26 & .000 \\
\hline & $\begin{array}{l}\text { Course } \\
\text { Clarity Prefs }\end{array}$ & .007 & .062 & .054 & 1.09 & .279 \\
\hline & $\begin{array}{l}\text { Social } \\
\text { Interaction } \\
\text { Prefs }\end{array}$ & -.126 & .054 & -.114 & -2.36 & .019 \\
\hline & Faculty & .003 & .084 & .019 & .355 & .723 \\
\hline & Gender & .006 & .079 & .037 & .755 & .451 \\
\hline & Year2006sp & .006 & .095 & .039 & .646 & .519 \\
\hline & Year2005 & -.008 & .102 & -.050 & -.802 & .423 \\
\hline & Year2004 & .006 & .113 & .034 & .523 & .601 \\
\hline & Status & -.009 & .081 & -.063 & -1.17 & .244 \\
\hline & $\begin{array}{l}\text { Previous } \\
\text { Experience }\end{array}$ & .007 & .068 & .047 & .997 & .319 \\
\hline & Age & .003 & .032 & .040 & .818 & .414 \\
\hline
\end{tabular}

Note. A simultaneous method of entry was used. $R$ Squared $=.373$ 
Bray, Aokyi \& Dlugosh

Table A7. Multiple regression coefficients (Item 21)

\begin{tabular}{|c|c|c|c|c|c|c|}
\hline & & $\begin{array}{l}\text { Unstandardized } \\
\text { Coefficients }\end{array}$ & & $\begin{array}{l}\text { Standardized } \\
\text { Coefficients }\end{array}$ & $\mathrm{t}$ & Sig. \\
\hline Model & & $\mathrm{B}$ & $\begin{array}{l}\text { Std. } \\
\text { Error }\end{array}$ & Beta & & \\
\hline \multirow[t]{16}{*}{1} & (Constant) & .868 & .517 & & 1.679 & .094 \\
\hline & $\begin{array}{l}\text { Motivation } \\
\text { Challenges }\end{array}$ & .485 & .087 & .361 & 5.538 & .000 \\
\hline & $\begin{array}{l}\text { Student } \\
\text { Interaction }\end{array}$ & .003 & .067 & .028 & .460 & .646 \\
\hline & $\begin{array}{l}\text { Course } \\
\text { Clarity }\end{array}$ & -.003 & .080 & -.028 & -.415 & .679 \\
\hline & $\begin{array}{l}\text { Teacher } \\
\text { Interaction }\end{array}$ & .005 & .081 & .045 & .640 & .522 \\
\hline & $\begin{array}{l}\text { Computer } \\
\text { Interaction }\end{array}$ & .160 & .084 & .109 & 1.908 & .057 \\
\hline & $\begin{array}{l}\text { Course } \\
\text { Clarity Prefs }\end{array}$ & .007 & .082 & .045 & .828 & .408 \\
\hline & $\begin{array}{l}\text { Social } \\
\text { Interaction } \\
\text { Prefs }\end{array}$ & .007 & .071 & .001 & .010 & .992 \\
\hline & Faculty & .109 & .112 & .057 & .976 & .330 \\
\hline & Gender & .006 & .105 & .032 & .593 & .553 \\
\hline & Year2006sp & .258 & .126 & .135 & 2.042 & .042 \\
\hline & Year2005 & .008 & .134 & .041 & .611 & .542 \\
\hline & Year2004 & .291 & .150 & .138 & 1.949 & .052 \\
\hline & Status & -.004 & .107 & -.025 & -.417 & .677 \\
\hline & $\begin{array}{l}\text { Previous } \\
\text { Experience }\end{array}$ & -.006 & .090 & -.032 & -.614 & .539 \\
\hline & Age & .006 & .005 & .073 & 1.342 & .181 \\
\hline
\end{tabular}

Note. A simultaneous method of entry was used. $R$ Squared $=.237$

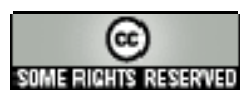

